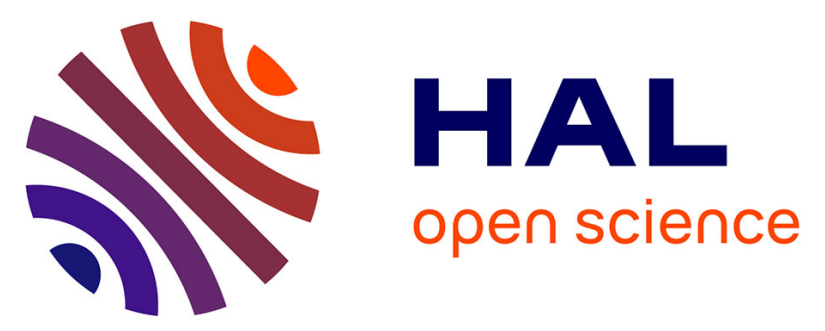

\title{
Independent association of PD-L1 expression with noninactivated VHL clear cell renal cell carcinoma-A finding with therapeutic potential
}

Solène-Florence Kammerer-Jacquet, Laurence Crouzet, Angélique Brunot, Julien Dagher, Adélaide Pladys, Julien Edeline, Brigitte Laguerre, Benoit Peyronnet, Romain Mathieu, Grégory Verhoest, et al.

\section{To cite this version:}

Solène-Florence Kammerer-Jacquet, Laurence Crouzet, Angélique Brunot, Julien Dagher, Adélaide Pladys, et al.. Independent association of PD-L1 expression with noninactivated VHL clear cell renal cell carcinoma-A finding with therapeutic potential. International Journal of Cancer, 2017, 140 (1), pp.142-148. 10.1002/ijc.30429 . hal-01439352

\section{HAL Id: hal-01439352}

\section{https://hal-univ-rennes1.archives-ouvertes.fr/hal-01439352}

Submitted on 12 Jul 2017

HAL is a multi-disciplinary open access archive for the deposit and dissemination of scientific research documents, whether they are published or not. The documents may come from teaching and research institutions in France or abroad, or from public or private research centers.
L'archive ouverte pluridisciplinaire HAL, est destinée au dépôt et à la diffusion de documents scientifiques de niveau recherche, publiés ou non, émanant des établissements d'enseignement et de recherche français ou étrangers, des laboratoires publics ou privés. 


\section{Independent association of PD-L1 expression with non-inactivated $V H L$ clear cell renal cell carcinoma - a finding with therapeutic potential}

Solène-Florence Kammerer-Jacquet, $\mathrm{MD}^{1,2}$, Laurence Crouzet, $\mathrm{MD}^{3}$, Angélique Brunot, $\mathrm{MBBS}^{3}$, Julien Dagher, $\mathrm{MD}^{1,2}$, Adélaïde Pladys ${ }^{4}$, Julien Edeline, MD, $\mathrm{PhD}^{3}$, Brigitte Laguerre, $\mathrm{MD}^{3}$, Benoit Peyronnet, $\mathrm{MD}^{5}$, Romain Mathieu, $\mathrm{MD}^{5}$, Grégory Verhoest, $\mathrm{MD}^{5}$, Jean-Jacques Patard, $\mathrm{MD}, \mathrm{PhD}^{6}$, Alexandra Lespagnol, $\mathrm{MD}^{7}$, Jean Mosser, $\mathrm{MD}, \mathrm{PhD}^{7}$, Marc Denis, $\mathrm{MD}, \mathrm{PhD}^{8}$, Yosra Messai, $\mathrm{PhD}^{9}$, Sophie Gad-Lapiteau, $\mathrm{PhD}^{9}$, Salem Chouaib, $\mathrm{PhD}^{9}$, Marc-Antoine Belaud-Rotureau, PharmD, $\mathrm{PhD}^{10,2}$, Karim Bensalah, MD, $\mathrm{PhD}^{5}$ and Nathalie Rioux-Leclercq, $\mathrm{MD}, \mathrm{PhD}^{1,2}$

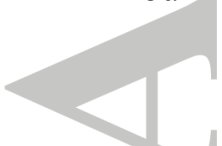

${ }^{1}$ University Hospital, Department of Pathology, Rennes, France

${ }^{2}$ UMR 6290-IGDR, Rennes, France

${ }^{3}$ Eugène Marquis Center, Department of Oncology, Rennes, France

${ }^{4}$ EHESP, Rennes, France

${ }^{5}$ University Hospital, Department of Urology, Rennes, France

${ }^{6}$ University Hospital, Department of Urology, Kremlin Bicêtre, France

${ }^{7}$ University Hospital, Department of Molecular Biology, Rennes, France

${ }^{8}$ University Hospital, Department of Molecular Biology, Nantes, France

${ }^{9}$ INSERM UMR1186, Laboratory Integrative Tumor Immunology and Genetic Oncology, Villejuif, France

${ }^{10}$ University Hospital, Department of Cytogenetics, Rennes, France

Keywords: clear cell renal cell carcinoma, PD-L1 expression, $V H L$ gene

Conflict of interest statement: The authors declare that there is no conflict of interest. 


\section{Corresponding author:}

Solene-Florence Kammerer-Jacquet

Service d'Anatomie Pathologique

CHU Pontchaillou

2 rue Henri Le Guilloux

35033 Rennes cedex 9

Telephone number: 0033299284279

Fax number: 0033299284284

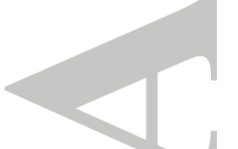

Research article: carcinogenesis

Keywords: clear cell renal cell carcinoma, PD-L1 expression, $V H L$ status, clinical outcome

Novelty and impact statements: In our retrospective series of 98 consecutive clear cell renal cell carcinoma (ccRCC), we identified an independent association between PD-L1 immunostaining and non-inactivated $V H L$ ccRCC. In particular wild-type $V H L$ ccRCC all expressed PD-L1. Wild-type $V H L$ ccRCC are a sub-group that are associated with a worse prognosis. These patients with PD-L1 expression may benefit from targeted immunotherapy.

Word count of text: 2371 words

Word count of the abstract: 248 words

Number of tables: 2

Number of figures: 3

Reference count: 32 


\section{ABSTRACT}

\section{C}

Clear cell renal cell carcinoma (ccRCC) is an aggressive tumor that is characterized in most cases by inactivation of the tumor suppressor gene $V H L$. The VHL/HIF/VEGF pathway thus plays a major role in angiogenesis and is currently targeted by anti-angiogenic therapy. The emergence of resistance is leading to the use of targeted immunotherapy against immune checkpoint PD1/PDL1 that restores antitumor immune response. The correlation between VHL status and PD-L1 expression has been little investigated.

In this study, we retrospectively reviewed 98 consecutive cases of ccRCC and correlated PDL1 expression by immunohistochemistry (IHC) with clinical data (up to 10-year follow-up), pathological criteria, VEGF, PAR-3, CAIX and PD-1 expressions by IHC and complete VHL status (deletion, mutation and promoter hypermethylation).

PD-L1 expression was observed in 69 ccRCC (70.4\%) and the corresponding patients had a worse prognosis, with a median specific survival of 52 months $(\mathrm{p}=0.03)$. PD-L1 expression was significantly associated with poor prognostic factors such as a higher ISUP nucleolar grade $(p=0.01)$, metastases at diagnosis $(p=0.01)$, a sarcomatoid component $(p=0.04)$, overexpression of VEGF $(p<0.01)$, and cytoplasmic PAR-3 expression $(p=0.01)$. PD-L1 expression was also associated with dense PD-1 expression $(\mathrm{p}=0.007)$ and with ccRCC with 0 or 1 alteration(s) (non-inactivated $V H L$ tumors) $(\mathrm{p}<0.01)$ that remained significant after multivariate analysis $(\mathrm{p}=0.004$ and $\mathrm{p}=0.024$, respectively). Interestingly, all wildtype VHL tumors (no VHL gene alteration, 11.2\%) expressed PD-L1.

In this study, we found PD-L1 expression to be associated with non-inactivated $V H L$ tumors and in particular wild-type $V H L$ ccRCC which may benefit from therapies inhibiting PDL1/PD-1.

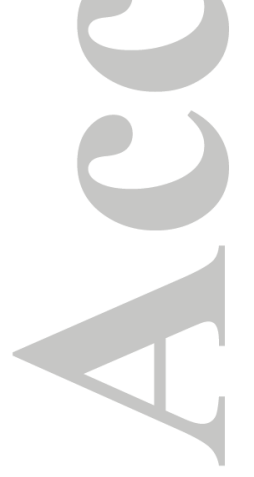




\section{INTRODUCTION}

Clear cell renal cell carcinoma (ccRCC) accounts for approximately $3 \%$ of adult cancers and is a very aggressive tumor with a $50 \%$ risk of metastases at initial diagnosis or follow-up. ${ }^{1}$

The VHL (von Hippel-Lindau) gene, located on chromosome 3p25, is a major tumor suppressor gene involved in ccRCC oncogenesis. ${ }^{2}$ Alterations of this gene occur in the majority of ccRCC through mutations or deletions and/or hypermethylation of its promoter ${ }^{3}$. VHL gene inactivation necessarily involves biallelic alterations in tumor cells, as both first and second "hits" must occur to be inactivated. However, a minority of ccRCC exhibit no or a single allele alteration on the $V H L$ gene. $^{4}$

The protein, pVHL, is a component of an E3 ubiquitin-ligase which targets the transcription factor: hypoxia-inducible factor (HIF). ${ }^{3}$ The consequence of pVHL impairment is a stabilization of HIF resulting in overexpression of HIF. This leads to the transcription of genes regulated by HIF, such as vascular endothelial growth factor $(V E G F)$ or carbonic anhydrase IX $(C A I X)$. Consequently, $V H L$ is one of the main triggers of the angiogenesis process in ccRCC. ${ }^{5}$ Based on an understanding of these mechanisms, therapies targeting angiogenesis emerged in the last decade, significantly improving the prognosis of metastatic ccRCC. ${ }^{6}$ However, the response is short-lived due to the development of resistance to these therapeutic agents. ${ }^{7}$

A new approach is based on targeted immunotherapy using checkpoint inhibitors since ccRCC is considered an immunogenic tumor with high numbers of mononuclear immune cells such as tumor-infiltrating lymphocytes (TIL). Recent studies showed that $15-56.5 \%$ of ccRCC have aberrant programmed death-ligand 1 (PD-L1/B7-H1/CD274) expression in the primary tumor. ${ }^{8-10} \mathrm{PD}-\mathrm{L} 1$ is a transmembrane protein which binds to its co-stimulatory receptor, PD-1 (B7-1), expressed by activated TILs, as a means to down-regulate antitumor immune responses by promoting TIL apoptosis and thus favor tumor progression. Recent clinical trials demonstrated that blocking the interaction between PD-1 and PD-L1 with monoclonal antibodies may result in anti-tumor activity as demonstrated in ccRCC. ${ }^{11}$

The aim of this study was to correlate PD-L1 expression with pathological criteria, expression of VEGF, PAR-3 (partitioning defective 3), CAIX, and PD-1, and complete VHL status in a population of patients with ccRCC and a long-term clinical follow-up of 10 years. 


\section{MATERIALS AND METHODS}

\section{Patients}

Consecutive patients operated for sporadic ccRCC in the Department of Urology at Rennes Hospital between 2002 and 2005 with a clinical follow-up of up to 10 years were retrospectively included in the study. All patients underwent radical nephrectomy without presurgical medication. The study protocol was approved by the local advisory board and informed consent was received from all patients prior to inclusion in the study.

\section{Tissue sample management}

Tumor samples were derived from biological sample processing by the Rennes Hospital Biological Resources Center (BB-0033-00056, http://www.crbsante-rennes.com/). The research protocol was conducted under French legal guidelines and met the requirements of the local institutional ethics committee. All consecutive ccRCC and paired renal cortex samples were analyzed. Immediately after macroscopic examination, small samples were collected from surgical specimens, frozen in liquid nitrogen and stored at $-80^{\circ} \mathrm{C}$ until DNA extraction. Genomic DNA was extracted from 25 to $35 \mathrm{mg}$ of frozen tissue sections using a QIAamp DNA minikit (Qiagen, Courtaboeuf, France). DNA quantity and quality were assessed by optical density (OD 260/280) measurement and $0.8 \%$ agarose gel electrophoresis using standard protocols.

\section{Pathological analysis}

After fresh tissue sampling surgical specimens were formalin-fixed. Paraffin sections were stained with hematoxylin and eosin-safran for light microscopy. All slides were reviewed by a dedicated uropathologist (NRL). The macroscopic and histological parameters analyzed were: tumor size, multifocality, nucleolar grade under the International Society of Urological Pathology (ISUP) grading system ${ }^{12}$, sarcomatoid pattern, tumor necrosis, granular component, lymphocyte infiltrate and microvessel invasion. Tumor stage was graded using the latest International Union Against Cancer Classification (2009). ${ }^{13}$ 


\section{Immunohistochemistry}

For each ccRCC case, a representative slide of the tumor with the highest nucleolar ISUP grade and the corresponding paraffin block were selected. The immunohistochemical analysis was double blinded and evaluated by two independent pathologists (SFKJ and NRL). Discordant cases were reevaluated collegially. Expression of VEGF (anti-VEGF antibody, sc152, dilution 1:100; Santa Cruz Biotechnology, Santa Cruz, CA, USA), CAIX (anti-CAIX antibody, ab15086, dilution 1:1500; Abcam, Cambridge, UK), PAR-3 (anti-PAR-3, HPA0300443, dilution 1:50; Sigma-Aldrich, St. Louis, USA) and PD-L1 (anti-PD-L1 antibody, clone 130021, dilution 1:200; R\&D Systems, Minneapolis, USA) was assessed by immunohistochemistry as previously described. ${ }^{4,14}$ The cut-off for overexpression was set at $85 \%$ of tumor cells for CAIX and $30 \%$ for VEGF., ${ }^{41}$ Only cytoplasmic PAR-3 expression was considered positive as previously assessed. ${ }^{15}$ PD-L1 was considered positive when any membranous or cytoplasmic tumor cell staining was observed. ${ }^{16}$ Regarding TILs, expression of CD3 (anti-CD3 antibody, clone SP7, dilution 1:100; Thermo Scientific, Waltham, MA, USA) and CD20 (anti-CD20 antibody, clone L26, dilution 1:25; Dako, Glostrup, Denmark) was assessed. The inflammatory extent was coded as 1 (sparse lymphocytes in the tumor) or 2 (marked dense lymphocytes or lymphoid nodules). Expression of PD-1 (anti-PD-1 antibody, clone NAT105, dilution 1:50; Abcam, Cambridge, UK) in TILs was scored as absent, rare, moderate or marked dense. Absence or rare density was considered negative whereas moderate or marked density was considered positive for statistical analysis.

\section{$V H L$ gene analysis}

We determined the complete $V H L$ status for each tumor by analyzing $V H L$ gene mutation, deletion and promoter methylation. Four primers pairs were designed (Primer3 software, Whitehead Research Institute, Cambridge, MA), to amplify two overlapping fragments for exon 1 (1A and 1B) and one fragment for each of exons 2 and 3 (Eurogentech, Belgium), covering part of the VHL 5'UTR, the entire coding sequence and exon-intron junctions (VHL Genbank accession AF010238). The 4 primers are presented in Table I (Supplementary tables). We amplified 50-150 ng of tumor DNA and of renal cortex DNA in parallel, using AmpliTaq Gold (Applera, Courtaboeuf, France) and the following PCR conditions: $95^{\circ} \mathrm{C} 9$ min and $95^{\circ} \mathrm{C} 1 \mathrm{~min}$, annealing $\mathrm{T}^{\circ} 45 \mathrm{sec}, 72^{\circ} \mathrm{C} 45 \mathrm{sec}, 35$ cycles, $\mathrm{MgCl} 21.5 \mathrm{mM}$, dNTP 200 
1M. DMSO [5\% (v/v), Eurobio] was added to amplify exons $1 \mathrm{~A}$ and $1 \mathrm{~B}$. $V H L$ mutations were detected with denaturing high-performance liquid chromatography (DHPLC) sequencing. DHPLC screening was carried out on a WAVE Nucleic Acid. Fragment Analysis system (Transgenomic, Glasgow, UK) with a DNAsep column. Forward and reverse automatic sequencing was performed using BigDye Terminator v1.1 Cycling Sequencing kit on an ABI Prism 3100 Genetic Analyser (Applied Biosystems, Courtaboeuf, France). All mutations were confirmed in a second round of PCR and via sequencing reactions. VHL gene deletions and promoter methylation were detected by multiplex ligation-dependent probe amplification (MLPA) analysis using the SALSA MLPA P016B VHL probe kit and SALSA MS-MLPA kit, respectively, as previously described. ${ }^{4}$ As $V H L$ functions as a tumor suppressor gene, impairments necessarily involve biallelic alterations in tumor cells as two hits are needed for inactivation to occur.

\section{Statistical analysis}

$\chi^{2}$, Fisher's exact and Mann-Whitney tests were performed to compare qualitative and quantitative parameters between the groups with and without PD-L1 expression, respectively. A logistic regression multivariate analysis was then performed using all significant variables from the univariate analysis $(\mathrm{p}<0.05)$. Cancer specific survival (CSS) according to PD-L1 expression was calculated from nephrectomy to death from cancer and Kaplan-Meier curves were compared by log-rank test. All p-values were 2-sided, and p-values less than 0.05 were considered statistically significant. All statistical analyses (AP) were performed using Stata 14.1 (StataCorp, College Station, TX, USA) software.

\section{RESULTS}

\section{Patients and pathological parameters}

The study retrospectively included 98 patients according to participant flow diagram (Figure I, supplementary figures). The median age at diagnosis was 64 years (40-84). Sixty-nine patients (70.4\%) had an ECOG performance status of 0. In 11 cases (11.2\%), nodal invasion was present at diagnosis and in 23 cases $(23.5 \%)$ patients had synchronous metastases. The mean tumor size was $7.3 \mathrm{~cm}+/-3.4 \mathrm{~cm}$ with tumors ranging from 1.5 to $18 \mathrm{~cm}$. The 
population characteristics and pathological parameters are summarized in Table 1. Table II (supplementary tables) details characteristics of metastatic patients.

\section{Genetic and epigenetic $V H L$ gene alteration}

All patients tested negative for germline mutations. A VHL gene mutation was found in 68 cases $(69.4 \%)$ and detailed in Table III (supplementary tables). Mutations occurred in exons 1, 2 and 3 in 28 (28.6\%), 26 (26.5\%) and 14 cases (14.3\%), respectively. Stop, frameshift, missense, and splice site mutations were found in 10 (10.2\%), 33 (33.7\%), $19(19.4 \%)$ and 6 $(6.1 \%)$ cases, respectively. VHL loss of heterozygosity and promoter methylation occurred in $71(72.4 \%)$ and 13 cases (13.3\%), respectively. At least one or more $V H L$ alterations were found in 87 cases $(88.8 \%)$. Tumors with two alterations of the $V H L$ gene ( $\mathrm{n}=65$ cases, $66.3 \%$ ) were deemed inactivated for that gene $(i n V H L)$. Those with no or only one alteration $(n=33$, $33.7 \%$ ) were grouped as non-inactivated $V H L$ tumors $(n i V H L)$. These included tumors with no $V H L$ gene alteration $(\mathrm{n}=11,11.2 \%)$ that were classed as wild type (wtVHL).

\section{Morphological and molecular phenotype of tumors with PD-L1 expression}

PD-L1 expression was observed in 69 tumors (70.4\%) with different patterns of expression (Figure 1 and Figure II, supplementary figures). These tumors were compared to tumors with no PD-L1 expression. Morphological and immunostainings for each markers are shown in Figures II to VI, supplementary figures. The results and statistical analysis are provided in Table 2. Tumors with PD-L1 expression were significantly associated with a higher tumor stage $(\mathrm{p}=0.035)$ and metastasis at diagnosis $(\mathrm{p}=0.010)$. Besides, these tumors had a higher ISUP nucleolar grade $(\mathrm{p}=0.009)$, sarcomatoid component $(\mathrm{p}=0.036)$, overexpression of VEGF $(\mathrm{p}=0.006)$, cytoplasmic expression of PAR-3 $(\mathrm{p}=0.010)$ and dense TIL PD-1 expression $(\mathrm{p}=0.007)$, as shown in Figure 2. PD-L1 expression was associated with niVHL ccRCC $(\mathrm{p}=0.007)$. Within the niVHL ccRCC group all wtVHL subgroup tumors expressed PD-L1 $(\mathrm{p}=0.030)$. The multivariate analysis (logistic regression) included all the significant factors except the sarcomatoid component which was already included in the ISUP nucleolar grade. Moderate or dense expression of PD-1 and the niVHL gene was significantly associated with PD-L1 expression in the multivariate analysis ( $\mathrm{p}=0.004$ and $\mathrm{p}=0.024$, respectively). 


\section{Correlation between PD-L1 expression and survival}

The progression of patients in the PD-L1 expression subgroup differed in comparison to patients with no PD-L1 expression in their tumors. The survival curves of the two subgroups are shown in Figure 3. Patients with PD-L1 expression had a worse prognosis with a median specific survival of 52 months from nephrectomy compared to patients with no PD-L1 expression for whom the median specific survival time was not reached $(p=0.030)$.

\section{DISCUSSION}

In our study, we correlated PD-L1 expression by IHC with pathological criteria, expression of VEGF, PAR-3, CAIX, and PD-1, and complete VHL status in a large series of 98 patients with ccRCC and a long-term clinical follow-up of up to 10 years.

As previously reported for ccRCC, in our series PD-L1 expression was associated with poor prognostic factors such as tumor stage, ISUP nucleolar grade, sarcomatoid component, dense PD-1 expression and VEGF expression. ${ }^{8,10,17-19}$ PD-L1 was also associated with cytoplasmic PAR-3 protein expression which was previously identified as a poor prognostic factor in ccRCC. ${ }^{15}$ Furthermore, as expected, patients with PD-L1 expression in ccRCC samples had a worse clinical outcome. ${ }^{8}$

As commonly reported, PD-L1 expression was associated with sarcomatoid components. ${ }^{19,20}$ For the first time, we found an association between PD-L1 expression and cytoplasmic PAR-3 expression. PAR-3 is a crucial component of partitioning-defective complex proteins that controls cell polarity and contributes to cell migration and cancer cell epithelial-tomesenchymal transition (EMT). ${ }^{21}$ PD-L1 expression associated with both sarcomatoid components and PAR-3 expression suggested potential EMT involvement in ccRCC. Recently, PD-L1 expression was reported to induce EMT in renal cell carcinoma through activation of SREBP-1c, a key transcription factor for lipogenesis genes. ${ }^{22}$

Two general mechanisms for the regulation of PD-L1 by tumor cells have emerged, namely innate immune resistance and adaptive immune resistance. ${ }^{23}$ For some tumors, it has been shown that PD-L1 expression is driven by constitutive oncogenic signaling pathways in tumor cells such as PI3K-AKT and MAPK pathways and is termed innate or constitutive immune resistance. ${ }^{24,25}$ A second alternative mechanism for PD-L1 regulation in tumor cells reflects 
their adaptation to endogenous tumor-specific immune responses, a process termed adaptive immune resistance. In this model, tumor cells use the natural physiology of PD-1 ligand induction to produce IFNs, notably IFN $\gamma .{ }^{26}$ In our series this mechanism is illustrated by dense PD-1 expression independently associated with PD-L1 expression.

For the first time, we correlated PD-L1 expression by IHC with VHL complete status including $V H L$ gene locus deletion, $V H L$ mutation and promoter hypermethylation. In our study, PD-L1 expression was independently associated with a niVHL status defined by 0 or 1 alterations of the $V H L$ gene. As a tumor suppressor gene, $V H L$ requires at least two events, one on each allele, to be inactivated as it is not a haploinsufficient tumor-suppressor gene. ${ }^{2}$ PD-L1 expression and niVHL ccRCC were also associated with poor prognostic factors such as VEGF expression. ${ }^{4,}{ }^{19}$ Furthermore, Beuselinck et al. reported PD-L1 expression and fewer $V H L$ gene mutations in ccrce4 tumors. This molecularly defined subtype of metastatic primary ccRCC was associated with poor prognosis under anti-angiogenic therapy. ${ }^{27}$ These data may indicate the occurrence of ccRCC with both PD-L1 expression and niVHL, as found in our series.

Recently, Messai et al. demonstrated that PD-L1 expression positively correlated with VHL inactivation through HIF-2 $\alpha{ }^{28}$ The difference in their conclusions may be due to population variations. In their study, 32 patients were retrospectively included: 21 patients with sporadic ccRCC and 11 with VHL-tumor associated ccRCC. Only one patient (3.1\%) had no VHL gene alteration at all. In our series, sporadic ccRCC was an inclusion criterion and $V H L$-tumor associated ccRCC cases were excluded. Among the 98 patients included, 11 patients $(11.2 \%)$ had a $w t V H L$ tumor with no $V H L$ gene alteration.

In our study, wtVHL ccRCC were particularly associated with PD-L1 expression. These results support the theory of alternative oncogenic pathways in ccRCC leading to PD-L1 overexpression despite HIF degradation due to the presence of an activated VHL protein (niVHL). Tumors with no inactivation of $V H L$ could use alternative pathways independent of VHL mechanisms such as the MAP kinase and PI3K-AKT-mTOR pathways involved in ccRCC oncogenesis. ${ }^{29-31}$ These alternative pathways have already been reported to induce PD-L1 expression in constitutive immune responses in other cancers. ${ }^{23,32}$

\section{CONCLUSION}


For the first time, we found PD-L1 expression by IHC to be associated with niVHL tumors, and in particular with $w t V H L$ ccRCC. These tumors may benefit from therapies inhibiting PDL1/PD-1.

\section{ACKNOWLEDGMENTS}

The authors would like to thank the Ligue Contre le Cancer, CORECT, Rennes Hospital and the French Institute of Cancer (INCa) for their financial support.

The authors would also like to thank the Rennes Hospital Biological Resources Center (BB0033-00056, http://www.crbsante-rennes.com/) for patient sample management as well as Pascale Bellaud and Roselyne Viel from the Histopathology platform H2P2-BIOSIT at the

Faculty of Medicine in Rennes for their technical support.

\section{REFERENCES}

1. Ljungberg B, Campbell SC, Choi HY, Jacqmin D, Lee JE, Weikert S, Kiemeney LA. The epidemiology of renal cell carcinoma. Eur Urol 2011;60: 615-21.

2. Gossage L, Eisen T, Maher ER. VHL, the story of a tumour suppressor gene. Nat Rev Cancer 2015;15: 55-64.

3. Kaelin WG, Jr. The von Hippel-Lindau tumor suppressor protein and clear cell renal carcinoma. Clin Cancer Res 2007;13: 680s-4s.

4. Patard JJ, Rioux-Leclercq N, Masson D, Zerrouki S, Jouan F, Collet N, Dubourg C, Lobel B, Denis M, Fergelot P. Absence of VHL gene alteration and high VEGF expression are associated with tumour aggressiveness and poor survival of renal-cell carcinoma. $\mathrm{Br} J$ Cancer 2009;101: 1417-24.

5. Banumathy G, Cairns P. Signaling pathways in renal cell carcinoma. Cancer Biol Ther 2010;10: 658-64.

6. Rini BI, Jaeger E, Weinberg V, Sein N, Chew K, Fong K, Simko J, Small EJ, Waldman FM. Clinical response to therapy targeted at vascular endothelial growth factor in metastatic renal cell carcinoma: impact of patient characteristics and Von Hippel-Lindau gene status. BJU Int 2006;98: 756-62.

7. Rini BI, Atkins MB. Resistance to targeted therapy in renal-cell carcinoma. Lancet Oncol 2009;10: 992-1000.

8. Leite KR, Reis ST, Junior JP, Zerati M, Gomes Dde O, Camara-Lopes LH, Srougi M. PD-L1 expression in renal cell carcinoma clear cell type is related to unfavorable prognosis. Diagnostic pathology 2015;10: 189.

9. Thompson RH, Dong H, Kwon ED. Implications of B7-H1 expression in clear cell carcinoma of the kidney for prognostication and therapy. Clin Cancer Res 2007;13: 709s-15s.

10. Thompson RH, Dong H, Lohse CM, Leibovich BC, Blute ML, Cheville JC, Kwon ED. PD-1 is expressed by tumor-infiltrating immune cells and is associated with poor outcome for patients with renal cell carcinoma. Clin Cancer Res 2007;13: 1757-61. 
11. Motzer RJ, Escudier B, McDermott DF, George S, Hammers HJ, Srinivas S, Tykodi SS, Sosman JA, Procopio G, Plimack ER, Castellano D, Choueiri TK, et al. Nivolumab versus Everolimus in Advanced Renal-Cell Carcinoma. $N$ Engl J Med 2015;373: 1803-13.

12. Delahunt B, Cheville JC, Martignoni G, Humphrey PA, Magi-Galluzzi C, McKenney J, Egevad L, Algaba F, Moch H, Grignon DJ, Montironi R, Srigley JR, et al. The International Society of Urological Pathology (ISUP) grading system for renal cell carcinoma and other prognostic parameters. The American journal of surgical pathology 2013;37: 1490504.

13. Martinez-Salamanca JI, Huang WC, Millan I, Bertini R, Bianco FJ, Carballido JA, Ciancio G, Hernandez C, Herranz F, Haferkamp A, Hohenfellner M, Hu B, et al. Prognostic impact of the 2009 UICC/AJCC TNM staging system for renal cell carcinoma with venous extension. Eur Urol 2011;59: 120-7.

14. Patard JJ, Fergelot P, Karakiewicz PI, Klatte T, Trinh QD, Rioux-Leclercq N, Said JW, Belldegrun AS, Pantuck AJ. Low CAIX expression and absence of VHL gene mutation are associated with tumor aggressiveness and poor survival of clear cell renal cell carcinoma. International journal of cancer Journal international du cancer 2008;123: 395-400.

15. Dagher J, Dugay F, Rioux-Leclercq N, Verhoest G, Oger E, Bensalah K, Cabillic F, Jouan F, Kammerer-Jacquet SF, Fergelot P, Vigneau C, Arlot-Bonnemains Y, et al. Cytoplasmic PAR-3 protein expression is associated with adverse prognostic factors in clear cell renal cell carcinoma and independently impacts survival. Human pathology 2014;45: 1639-46.

16. Choueiri TK, Figueroa DJ, Fay AP, Signoretti S, Liu Y, Gagnon R, Deen K, Carpenter C, Benson P, Ho TH, Pandite L, de Souza P, et al. Correlation of PD-L1 Tumor Expression and Treatment Outcomes in Patients with Renal Cell Carcinoma Receiving Sunitinib or Pazopanib: Results from COMPARZ, a Randomized Controlled Trial. Clin Cancer Res 2015;21: 1071-7.

17. Thompson RH, Kuntz SM, Leibovich BC, Dong H, Lohse CM, Webster WS, Sengupta S, Frank I, Parker AS, Zincke H, Blute ML, Sebo TJ, et al. Tumor B7-H1 is associated with poor prognosis in renal cell carcinoma patients with long-term follow-up. Cancer research 2006;66: 3381-5.

18. Joseph RW, Millis SZ, Carballido EM, Bryant D, Gatalica Z, Reddy S, Bryce AH, Vogelzang NJ, Stanton ML, Castle EP, Ho TH. PD-1 and PD-L1 Expression in Renal Cell Carcinoma with Sarcomatoid Differentiation. Cancer immunology research 2015;3: 1303-7.

19. Shin SJ, Jeon YK, Kim PJ, Cho YM, Koh J, Chung DH, Go H. Clinicopathologic Analysis of PD-L1 and PD-L2 Expression in Renal Cell Carcinoma: Association with Oncogenic Proteins Status. Ann Surg Oncol 2015.

20. Joseph RW, Millis SZ, Carballido EM, Bryant D, Gatalica Z, Reddy S, Bryce AH, Vogelzang NJ, Stanton ML, Castle EP, Ho TH. PD-1 and PD-L1 Expression in Renal Cell Carcinoma With Sarcomatoid Differentiation. Cancer immunology research 2015.

21. Jan YJ, Ko BS, Liu TA, Wu YM, Liang SM, Chen SC, Wang J, Liou JY. Expression of partitioning defective 3 (Par-3) for predicting extrahepatic metastasis and survival with hepatocellular carcinoma. Int J Mol Sci 2013;14: 1684-97.

22. Wang Y, Wang H, Zhao Q, Xia Y, Hu X, Guo J. PD-L1 induces epithelial-tomesenchymal transition via activating SREBP-1c in renal cell carcinoma. Med Oncol 2015;32: 212.

23. Ritprajak P, Azuma M. Intrinsic and extrinsic control of expression of the immunoregulatory molecule PD-L1 in epithelial cells and squamous cell carcinoma. Oral oncology 2015;51: 221-8. 
24. Atefi M, Avramis E, Lassen A, Wong DJ, Robert L, Foulad D, Cerniglia M, Titz B, Chodon T, Graeber TG, Comin-Anduix B, Ribas A. Effects of MAPK and PI3K pathways on PD-L1 expression in melanoma. Clin Cancer Res 2014;20: 3446-57.

25. Chen J, Jiang CC, Jin L, Zhang XD. Regulation of PD-L1: a novel role of prosurvival signalling in cancer. Annals of oncology : official journal of the European Society for Medical Oncology / ESMO 2016;27: 409-16.

26. Schalper KA. PD-L1 expression and tumor-infiltrating lymphocytes: Revisiting the antitumor immune response potential in breast cancer. Oncoimmunology 2014;3: e29288.

27. Beuselinck B, Job S, Becht E, Karadimou A, Verkarre V, Couchy G, Giraldo N, Rioux-Leclercq N, Molinie V, Sibony M, Elaidi R, Teghom C, et al. Molecular Subtypes of Clear Cell Renal Cell Carcinoma Are Associated with Sunitinib Response in the Metastatic Setting. Clin Cancer Res 2015.

28. Messai Y, Gad S, Noman MZ, Le Teuff G, Couve S, Janji B, Kammerer SF, Rioux-Leclerc N, Hasmim M, Ferlicot S, Baud V, Mejean A, et al. Renal Cell Carcinoma Programmed Death-ligand 1, a New Direct Target of Hypoxia-inducible Factor-2 Alpha, is Regulated by von Hippel-Lindau Gene Mutation Status. Eur Urol 2015.

29. Robb VA, Karbowniczek M, Klein-Szanto AJ, Henske EP. Activation of the mTOR signaling pathway in renal clear cell carcinoma. The Journal of urology 2007;177: $346-52$.

30. Mendoza MC, Er EE, Blenis J. The Ras-ERK and PI3K-mTOR pathways: crosstalk and compensation. Trends Biochem Sci 2011;36: 320-8.

31. Huang D, Ding Y, Luo WM, Bender S, Qian CN, Kort E, Zhang ZF, VandenBeldt K, Duesbery NS, Resau JH, Teh BT. Inhibition of MAPK kinase signaling pathways suppressed renal cell carcinoma growth and angiogenesis in vivo. Cancer research 2008;68: 81-8.

32. Lastwika KJ, Wilson W, 3rd, Li QK, Norris J, Xu H, Ghazarian SR, Kitagawa H, Kawabata S, Taube JM, Yao S, Liu LN, Gills JJ, et al. Control of PD-L1 Expression by Oncogenic Activation of the AKT-mTOR Pathway in Non-Small Cell Lung Cancer. Cancer research 2016;76: 227-38. 


\section{Tables}

Table 1. Summary of the clinical and histopathological characteristics of 98 patients with sporadic ccRCC.

\begin{tabular}{|c|c|}
\hline Variables & Number of patients (\%) \\
\hline Sex & \\
\hline M & $60(61.2 \%)$ \\
\hline $\mathrm{F}$ & $38(38.8 \%)$ \\
\hline ECOG & \\
\hline 0 & $64(65.3 \%)$ \\
\hline 1 & $34(34.7 \%)$ \\
\hline Age (years) & $64(40-84)$ \\
\hline Tumour size $(\mathrm{cm})$ & $7.3(1.5-18)$ \\
\hline Nucleolar grade & \\
\hline 1 & $2(2 \%)$ \\
\hline 2 & $33(33.7 \%)$ \\
\hline 3 & $32(32.7 \%)$ \\
\hline 4 & $31(31.6 \%)$ \\
\hline Tumour stage (pT) & \\
\hline 1 & $37(37.8 \%)$ \\
\hline 2 & $18(18.4 \%)$ \\
\hline 3 & $39(39.8 \%)$ \\
\hline 4 & $4(4.1 \%)$ \\
\hline Lymph node status $(\mathrm{pN})$ & \\
\hline 0 & $88(89.8 \%)$ \\
\hline $1-2$ & $10(10.2 \%)$ \\
\hline Metastasis status (pM) & \\
\hline 0 & $70(71.4 \%)$ \\
\hline 1 & $28(28.6 \%)$ \\
\hline Recurrence & \\
\hline Local recurrence & $6(6.1 \%)$ \\
\hline Metastases & $20(20.4 \%)$ \\
\hline
\end{tabular}




\section{Table 2. Summary of histopathological and immunohistochemical characteristics and}

\section{$V H L$ status of tumors according to PD-L1 expression.}

\begin{tabular}{|c|c|c|c|c|}
\hline Variables & $\begin{array}{l}\text { No expression of } \\
\text { PD-L1 }(n=29)\end{array}$ & $\begin{array}{l}\text { Expression of } \\
\text { PD-L1 }(n=69)\end{array}$ & $\begin{array}{l}\text { Univariate analysis, } \\
\text { p-value }\end{array}$ & $\begin{array}{l}\text { Multivariate analysis, } \\
\text { p-value }\end{array}$ \\
\hline Tumour stage (T3-T4) & 8 & 34 & $\mathrm{p}=\mathbf{0 . 0 3 5} \dagger$ & $\mathrm{p}=0.232$ \\
\hline Lymph node status (N1-N2) & 3 & 8 & $\mathrm{p}=1 \dagger$ & \\
\hline Metastasis at diagnosis (M) & 3 & 25 & $\mathbf{p}=\mathbf{0 . 0 1 0} \uparrow$ & $\mathrm{p}=0.166$ \\
\hline Median tumor size $(\mathrm{cm})$ & 7.5 & 8.2 & $\mathrm{p}=0.094 \S$ & \\
\hline ISUP nucleolar grade (3-4) & 13 & 50 & $\mathrm{p}=0.009 \dagger$ & $\mathrm{p}=0.781$ \\
\hline Tumour necrosis & 12 & 41 & $\mathrm{p}=0.102 \dagger$ & \\
\hline Sarcomatoid component & 1 & 14 & $p=0.036$ & \\
\hline Granular component & 12 & 39 & $\mathrm{p}=0.171 \dagger$ & \\
\hline Microvascular invasion & 9 & 30 & $\mathrm{p}=0.251 \uparrow$ & \\
\hline Dense lymphocyte infiltrate & 2 & 12 & $\mathrm{p}=0.220 \%$ & \\
\hline VEGF expression $\geq 30 \%$ & 8 & 38 & $\mathrm{p}=0.006 \dagger$ & $\mathrm{p}=0.891$ \\
\hline CAIX expression $\geq 85 \%$ & 25 & 49 & $\mathrm{p}=0.110 \dagger$ & \\
\hline Cytoplasmic PAR-3 expression & 9 & 41 & $\mathbf{p}=\mathbf{0 . 0 1 0} \dagger$ & $\mathrm{p}=0.835$ \\
\hline Moderate or dense PD-1 expression & 5 & 32 & $\mathbf{p}=\mathbf{0 . 0 0 7} \dagger$ & $p=0.004$ \\
\hline Non inactivated $V H L$ status & 4 & 29 & $\mathrm{p}=0.007 \dagger$ & $p=0.024$ \\
\hline Wild-type $V H L$ & 0 & 11 & $p=0.030 \uparrow$ & \\
\hline
\end{tabular}

Note: $\dagger$ Pearson chi2 test, $\ddagger$ Fisher's exact test, $\S$ Mann-Whitney tests 


\section{Figures}

Figure 1. Intensity of PDL1 expression
A) Absence of PDL1 expression, IHC x100
B) Low expression of PDL1 in tumor cells, IHC x100
C) Moderate expression of PDL1 in tumor cells, IHC x100
D) High expression of PDL1 in tumor cells, IHC x100
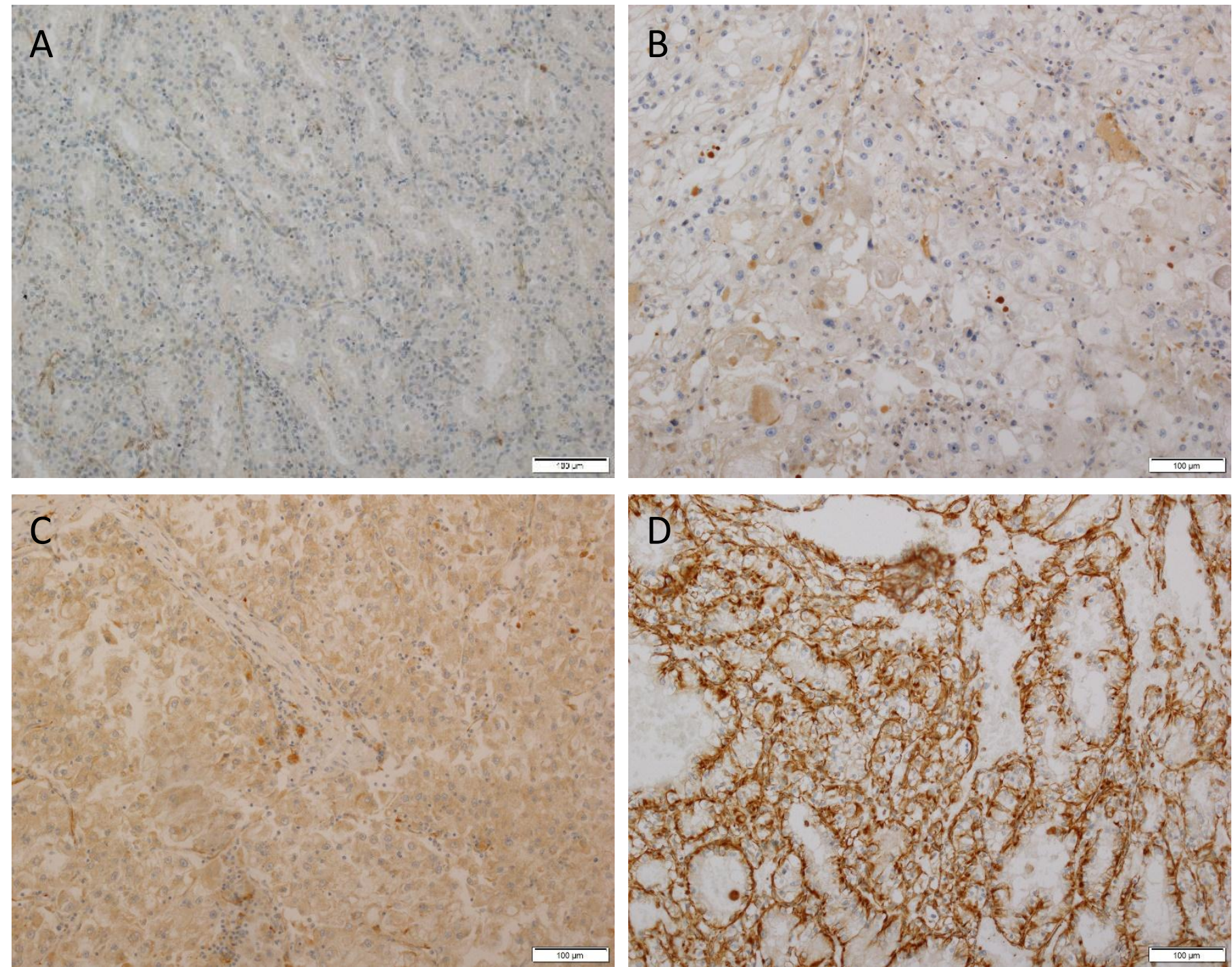
Figure 2. Pathological and immunohistochemical parameters associated with PD-L1 expression

A) Sarcomatoid component, HES x100

B) Cytoplasmic and membranous expression of PAR-3, IHC x100

C) Diffuse cytoplasmic expression of VEGFA, IHC x100

D) Dense PD-1 expression in tumor-infiltrating lymphocytes, IHC x100
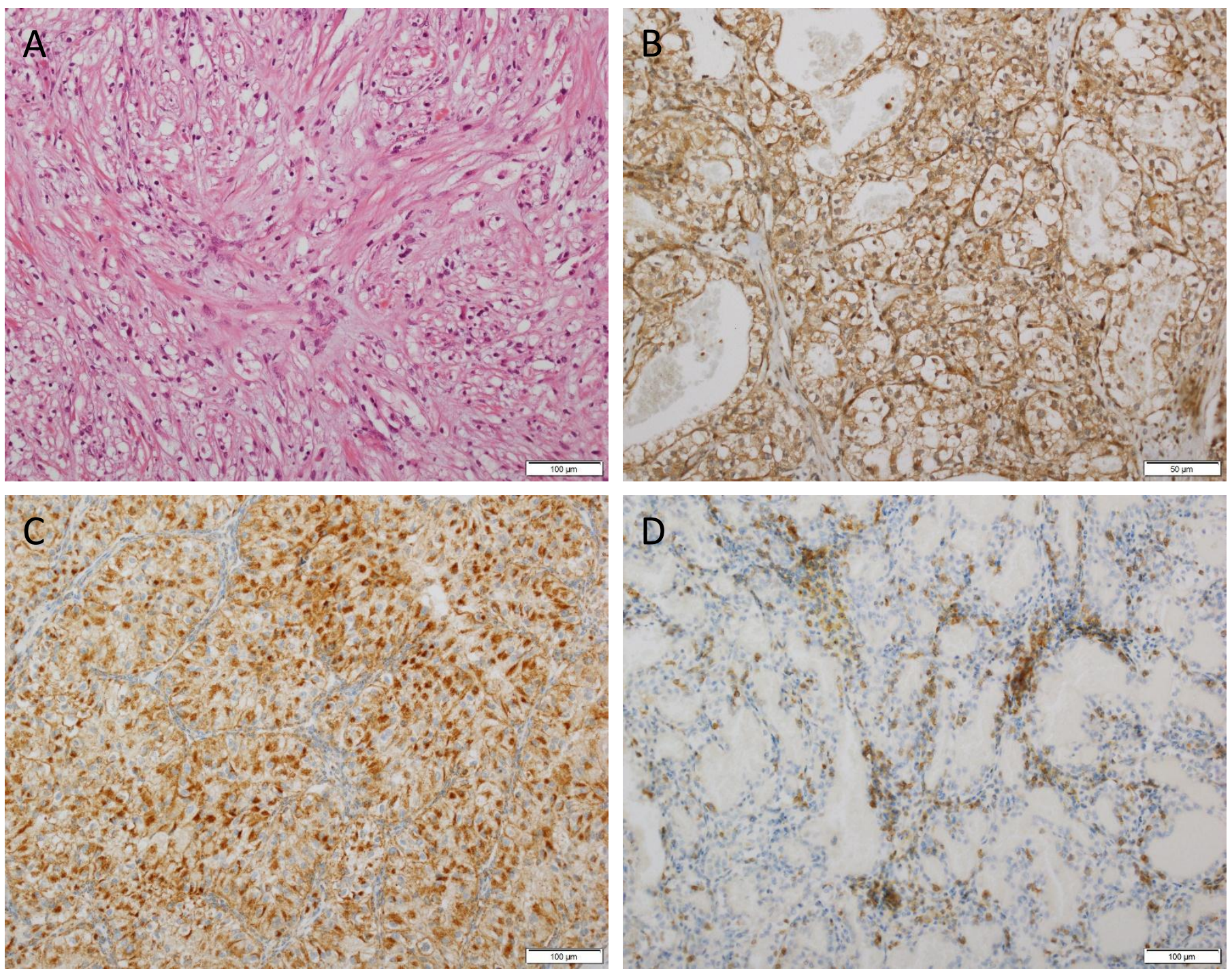
Figure 3. Kaplan-Meier curve representing cancer specific survival according to PD-L1 expression
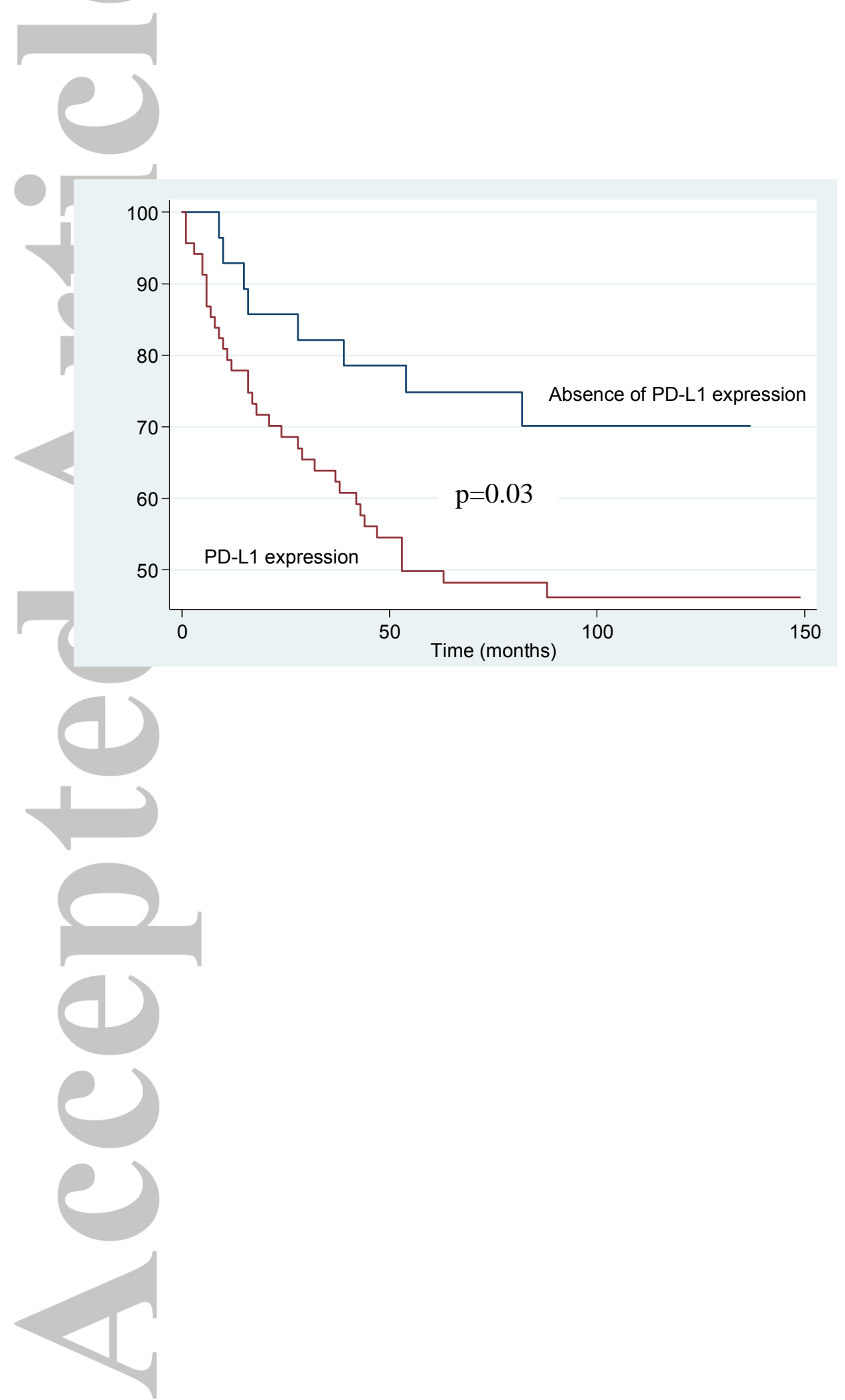